\title{
Body Composition After Endogenous (Cushing's Syndrome) and Exogenous (Rheumatoid Arthritis) Exposure to Glucocorticoids
}

Authors

Affiliations
E. Resmini ${ }^{1}$, C. Farkas ${ }^{1}$, B. Murillo ${ }^{1}$, M.-J. Barahona ${ }^{1,2}$, A. Santos ${ }^{1}$, M. A. Martínez-Momblán ${ }^{1}$, O. Roig ${ }^{1}$, J. Ybarra ${ }^{1}$, C. Geli ${ }^{3}$, S. M. Webb

${ }^{1}$ Instituto de Investigación Biomédica (IIB)-Sant Pau, Endocrinology/Medicine Department and Centro de Investigación Biomédica en Red de Enfermedades Raras (CIBER-ER, Unidad), ISCIII; Universitat Autonoma de Barcelona, Spain 2Endocrinology Department, Hospital Universitari Mútua de Terrassa, Barcelona, Spain ${ }^{3}$ Rheumatology Department, Hospital Sant Pau, Barcelona, Spain
Key words

- body composition

- cushing's syndrome

- rheumatoid arthritis

- glucocorticoids received 03.03 .2010 accepted 03.05 .2010

\section{Bibliography} DOI http://dx.doi.org/ 10.1055/s-0030-1255032 Horm Metab Res 2010;

42: 1-6

(c) Georg Thieme Verlag KG Stuttgart · New York ISSN 0018-5043

\section{Correspondence}

\section{E. Resmini, MD}

Department of Endocrinology Hospital de Sant Pau

C. S. Antoni Maria Claret n.167 08025 Barcelona

Spain

Tel.: + 34/9355/37 917

Fax: + 34/9355/65 602

eresmini@santpau.cat

\section{Abstract \\ $\nabla$}

Exposure to chronic glucocorticoid (GC) excess determines changes in body composition. The aim of the study was to compare body composition in women exposed to endogenous hypercortisolism (Cushing's syndrome, CS), and exogenous glucocorticoid treatment (rheumatoid arthritis, RA) and controls. 51 CS women, 26 RA women treated with low-dose prednisone $(5 \mathrm{mg} /$ day or $10 \mathrm{mg} / 2$ days), and 78 female controls were included. 14 CS patients were hypercortisolemic, 37 in remission (10 required hydrocortisone substitution after surgery). Body composition parameters were measured by dual-energy Xray absorptiometry scanning (DEXA). RA patients had a greater waist-hip ratio (WHR) $(\mathrm{p}<0.01)$, less lean body mass (LBM) $(\mathrm{p}<0.01)$, and lumbar bone mineral density (BMD) $(p<0.01)$ than controls. CS patients, globally and those with cured disease, had more total fat (both percent- age and $\mathrm{kg}$ ) and trunk fat percentage, and less whole body-BMD than RA patients $(\mathrm{p}<0.05$, $\mathrm{p}<0.01, \mathrm{p}<0.05$, respectively). Active CS patients had less whole body-BMD and more LBM than RA patients $(\mathrm{p}<0.05, \mathrm{p}=0.01$, respectively). Cured CS patients not taking hydrocortisone had more total fat [both percentage $(\mathrm{p}<0.05)$ and $\mathrm{kg}$ $(p<0.05)$ ], trunk fat percentage $(p<0.05)$, lumbar BMD $(\mathrm{p}<0.01)$ than RA patients. Cured CS patients requiring hydrocortisone only differed from RA patients by smaller WHR $(\mathrm{p}<0.01)$. All the differences in BMD disappeared when the data were reanalyzed including only the estrogen-deficient groups. Hypercortisolism of CS determines an irreversible increase in body fat, greater than in RA. Endogenous and exogenous exposure to GC negatively affects body composition by increasing the WHR. There appears to be no additional effect on BMD in estrogen-deficient women.

\section{Introduction}

\section{$\nabla$}

Exposure to chronic glucocorticoid (GC) excess produces marked changes in body composition, reducing bone mass and lean body mass, and favoring central fat accumulation [1,2]. Cushing's syndrome (CS) is a rare endocrine disease characterized by cortisol hypersecretion, mainly by a pituitary tumor (Cushing's disease) or, less frequently, by an adrenal or an ectopic neuroendocrine tumor. Changes in body composition in CS include increased fat mass, decreased bone mass, thinning of the skin, and reduced lean mass. Why these tissues are affected so dramatically is unclear [3]. Glucocorticoids (GCs) regulate lipid metabolism through promoting lipogenesis in adipose tissue [4].

An increase in visceral fat in both male and female patients with CS has been reported, with the abolition of the normal male to female difference in visceral fat [5]. It has been assumed that resolution of hypercortisolism is followed by normalization of body composition; a decrease in fat mass has been reported in the early recovery after successful treatment of CS [6,7]. However, patients who have suffered from CS, often complain of central obesity, despite successful treatment, which may even have rendered them adrenal insufficient. Persistence of increased cardiovascular risk and carotid atherosclerosis has been reported in patients with CS after five years of cure [8]. Moreover, there could be a relationship between cortisol and fasting glucose [9]. Rheumatoid arthritis (RA) is a chronic, systemic inflammatory disorder that may affect many tissues and organs, but principally attacks the joints producing an inflammatory synovitis that often progresses to destruction of the articular carti- 
lage and ankylosis of the joints. RA can also produce diffuse inflammation in the lungs, pericardium, pleura, and sclera, and also nodular lesions, most common in subcutaneous tissue under the skin. Although the cause of RA is unknown, autoimmunity plays a pivotal role in its chronicity and progression.

Various treatments, including nonpharmacological physical therapy and occupational therapy are available. Analgesia (painkillers) and anti-inflammatory drugs, as well as steroids are used to suppress symptoms, while disease-modifying antirheumatic drugs (DMARDs) are often required to inhibit or halt the underlying immune process and prevent long-term damage [10]. For sustained improvement in a chronic disease such as RA, it appears that GC must be given more or less continuously [11], but unwanted signs of hormonal excess have been reported in $40 \%$ of cases at some time, during the course of treatment. Most of them are considered mild or transient and disappear or lessen if the doses of GC are reduced, often followed also by a decline in the degree of improvement [11].

Few data are available on body composition parameters in CS and no data are available on the comparison of body composition parameters in endogenous versus exogenous GC exposure. While CS is a rare condition, exposure to exogenous GC is a common situation in clinical practice, for a variety of causes. It can be assumed that no ideal group of healthy women taking GC chronically can exist. Thus, when considering a group of CS patients we selected those with RA, since both these conditions predominate in females, who are not associated with malignancy and have chronic diseases treated in ambulatory care.

The aim of this study was to compare body composition parameters after exposure to endogenous hypercortisolism (due to Cushing's syndrome) and exogenous GC treatment (with lowdose prednisone in rheumatoid arthritis) with healthy controls.

\section{Patients and Methods \\ $\nabla$}

\section{Patients}

A total of 51 women with CS were included (mean age $51.4 \pm 13.5$ years). At the time of the study, $14 \mathrm{CS}$ patients were hypercortisolemic (i.e., active, 12 of pituitary and 2 of adrenal origin) and 37 were in remission (i.e., cured, 27 of pituitary and 10 of adrenal origin). CS was considered in remission if either adrenal insufficiency was demonstrated [basal AM cortisol $<100 \mathrm{nmol} / \mathrm{l}$ $(<4 \mu \mathrm{g} / \mathrm{dl})$ and/or undetectable 24-h free urinary cortisol] or morning cortisol suppression ( $<50 \mathrm{nmol} / \mathrm{l},<1.8 \mu \mathrm{g} / \mathrm{dl}$ ) after $1 \mathrm{mg}$ dexamethasone overnight was observed. Of the 37 in remission, 10 were adrenal insufficient at the time of the evaluation and required substitution therapy with hydrocortisone (mean of $20 \mathrm{mg}$ every day), while the other 27 had presented transient hypocortisolism after surgery, but did not currently require substitution therapy.

The mean time of hormonal cure since normalization of cortisol to study date was $11 \pm 6$ years (range, $0.7-22$ years). The mean duration of endogenous hypercortisolism was $70 \pm 5$ months. Duration of hypercortisolism was considered as the period of time between symptoms onset (as referred by the patients) and the diagnosis of CS plus the period of time between diagnosis and remission of hypercortisolism after treatment. Information on pituitary function (GH, IGF-I, TSH, free T4, prolactin) and estrogen status were collected. 7 patients were $\mathrm{GH}$-deficient (3 of them were treated with recombinant human $\mathrm{GH}$ ), 5 were hypothyroid (all on L-thyroxine replacement), 25 were estrogendeficient (17 cured and 8 active, 2 gonadotropin deficient, 23 menopausal), while the other 26 were estrogen-sufficient (20 cured, 6 active).

26 women with RA (mean age $62.0 \pm 10.1$ years) who required treatment with low doses of prednisone $(5 \mathrm{mg}$ every day or $10 \mathrm{mg}$ every 2 days) were included, from the Rheumatology Department of our hospital. Diagnostic criteria for RA are those proposed by the American College of Rheumatology (ACR) for classification of the disease [12].

Mean duration of exogenous GC treatment was $65 \pm 6$ months. This dose of prednisone was chosen since $5 \mathrm{mg}$ prednisone is considered to be equivalent to $20 \mathrm{mg}$ of hydrocortisone [13]. Information on thyroid function and estrogen status was collected: 3 were hypothyroid (all on L-thyroxine replacement), 22 were estrogen-deficient (menopausal), and 4 were estrogen-sufficient (Table 1).

78 healthy control women, (mean age $53.71 \pm 12.97$ years), were selected from the blood donors' database at our hospital. They have routine blood test and a complete medical history at our hospital. Letters were sent to controls, and a phone call was made one week later; the first control to accept was included. Controls that referred GC treatment or malignant diseases were excluded.

All patients and controls signed an informed consent after study approval by the hospital ethics committee.

\section{Methods}

Lumbar spine and whole body bone mineral density (BMD) and body composition [lean body mass LBM), whole and trunkal fat mass (FM) and total mass] were measured by dual-energy X-ray absorptiometry scanning (DEXA, Delphi QDR 4500, Hologic, Vilvoorde, Belgium) in both patients and controls. The mean preci-

\begin{tabular}{|c|c|c|}
\hline & $\begin{array}{l}\text { CS } \\
(n=51)\end{array}$ & $\begin{array}{l}\text { RA } \\
(n=26)\end{array}$ \\
\hline Age (years) & $51.4 \pm 13.5$ & $62.0 \pm 10.1$ \\
\hline Duration of endogenous hypercortisolism (months) & $70 \pm 5$ & - \\
\hline Duration of exogenous GC treatment (months) & - & $65 \pm 6$ \\
\hline Clinical control & Cured $=37$, Active $=14$ & - \\
\hline $\begin{array}{l}\text { Adrenal insufficiency, requiring hydrocortisone } \\
\text { (20 mg/day) }\end{array}$ & 10 & - \\
\hline Estrogen status & $\begin{array}{l}\text { Estrogen deficient }=25 \\
\text { Estrogen sufficient }=26\end{array}$ & $\begin{array}{l}\text { Estrogen deficient }=22 \\
\text { Estrogen sufficient }=4\end{array}$ \\
\hline GH status & $\begin{array}{l}\text { GH deficient }=7 \text { ( } 3 \text { on replacement } \\
\text { therapy) } \\
\text { GH sufficient }=44\end{array}$ & - \\
\hline
\end{tabular}

Table 1 Clinical parameters in patients with Cushing's syndrome and rheumatoid arthritis 
Table 2 Body composition parameters in patients with Cushing's syndrome and rheumatoid arthritis and controls ${ }^{\mathrm{a}}$

\begin{tabular}{|c|c|c|c|c|c|c|}
\hline & $\begin{array}{l}\text { CS } \\
(n=51)\end{array}$ & $\begin{array}{l}\text { RA } \\
(n=26)\end{array}$ & $\begin{array}{l}\text { Controls } \\
(n=78)\end{array}$ & $\mathbf{p}^{1}$ & $p^{2}$ & $p^{3}$ \\
\hline BMI $\left(\mathrm{kg} / \mathrm{m}^{2}\right)$ & $27.8 \pm 6.0$ & $26.3 \pm 5.9$ & $26.2 \pm 5.3$ & 0.36 & 1.00 & 0.86 \\
\hline Waist hip ratio & $0.90 \pm 0.0$ & $0.94 \pm 0.2$ & $0.83 \pm 0.6$ & $<0.01$ & $<0.01$ & 0.31 \\
\hline Total fat mass (\%) & $39.7 \pm 7.0$ & $37.8 \pm 7.0$ & $35.5 \pm 7.0$ & $<0.01$ & 0.89 & $<0.05$ \\
\hline Total fat mass $(\mathrm{kg})$ & $27.6 \pm 10.1$ & $23.5 \pm 8.1$ & $23.8 \pm 7.8$ & 0.05 & 0.15 & $<0.05$ \\
\hline Trunk fat mass (\%) & $40.7 \pm 8.5$ & $36.8 \pm 8.3$ & $34.0 \pm 8.7$ & $<0.01$ & 0.81 & $<0.01$ \\
\hline Trunk fat mass (kg) & $14.2 \pm 5.7$ & $12.2 \pm 6.5$ & $11.2 \pm 4.5$ & $<0.01$ & 0.77 & 0.10 \\
\hline Lean body mass $(\mathrm{kg})$ & $38.2 \pm 5.9$ & $35.4 \pm 5.1$ & $39.7 \pm 4.2$ & 0.10 & $<0.01$ & 0.20 \\
\hline Whole-BMD $\left(\mathrm{g} / \mathrm{cm}^{2}\right)$ & $1.04 \pm 0.1$ & $1.1 \pm 0.2$ & $1.1 \pm 0.1$ & $<0.05$ & 0.19 & $<0.05$ \\
\hline Lumbar BMD $\left(\mathrm{g} / \mathrm{cm}^{2}\right)$ & $1.02 \pm 0.2$ & $0.9 \pm 1.2$ & $1.1 \pm 1.2$ & $<0.05$ & $<0.01$ & 0.13 \\
\hline
\end{tabular}

${ }^{a} \mathrm{p}^{1}$ between $\mathrm{CS}$ and controls; $\mathrm{p}^{2}$ between RA and controls; $\mathrm{p}^{3}$ between CS and RA

A p-value of $<0.05$ was considered significant

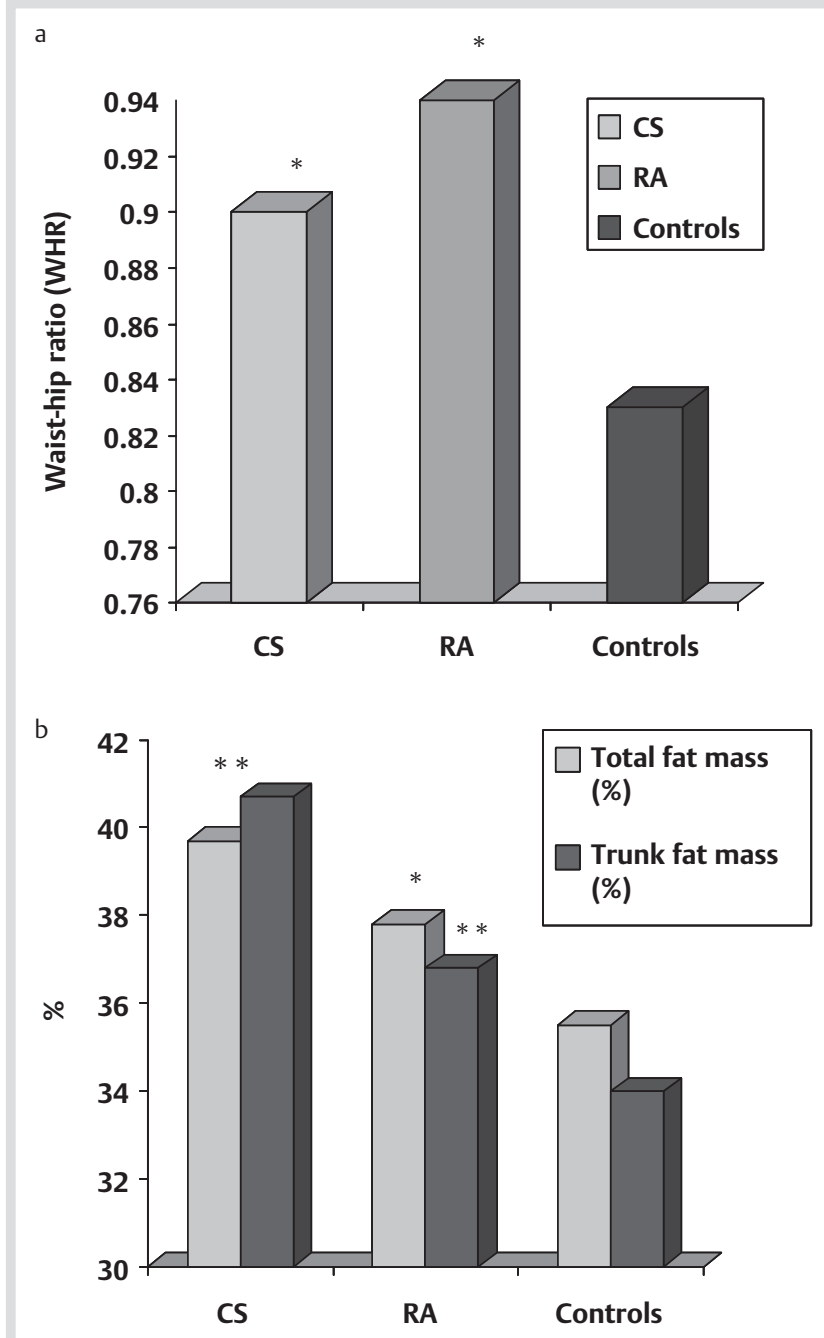

Fig. 1 a: Waist-hip ratio (WHR) in patients and controls: * $p<0.01$, between CS and controls and between RA and controls. b: Total fat and trunk fat mass (percentage) in patients and controls. Total fat mass: ${ }^{*} \mathrm{p}<0.01$ between $\mathrm{CS}$ and controls; ${ }^{* *} \mathrm{p}<0.05$ between CS and RA. Trunk fat mass: ${ }^{*} \mathrm{p}<0.01$ between CS and controls and between CS and RA.

sion error (coefficient of variation) was 1\%. Furthermore, anthropometric parameters (weight, height, body mass index, waist, and hip circumference) and sitting blood pressure (BP) were measured.

\section{Statistical analysis}

Quantitative data are expressed as mean and SD (Gaussian distribution). Data distribution was analyzed by the KolmogorovSmirnov test. Comparisons between 3 groups were performed firstly with an ANOVA and ANCOVA tests (using age as covariant) to correct for age differences between the groups. If the comparisons showed significant differences, pairwise comparisons were done as a Bonferroni post-hoc test. Secondly, comparisons between the estrogen deficient patients in each group were performed with an ANOVA and Bonferroni post hoc test. A p-value of $<0.05$ was considered significant. Analysis was performed using SPSS 17.0 statistical package for Windows (SPSS Inc., Chicago, IL, USA).

\section{Results}

$\nabla$

\section{Comparisons between rheumatoid arthritis (RA) patients and controls}

Patients with RA had a greater waist-hip ratio $(p<0.01)$ and less lean body mass (LBM) $(\mathrm{p}<0.01)$ and lumbar BMD $(\mathrm{p}<0.01)$ than controls (Table 2).

\section{Comparisons between Cushing's syndrome (CS) patients and controls}

Patients with CS as a whole group had more total fat [both in percentage $(p<0.01)$ and in $\mathrm{kg}(\mathrm{p}=0.05)$ ] and trunk fat [both in percentage $(p<0.01)$ and in $\mathrm{kg}(\mathrm{p}<0.01)]$, waist $(\mathrm{p}=0.02)$, and a greater waist-hip ratio $(\mathrm{p}<0.01)$ than controls. CS patients had less whole body-BMD $(\mathrm{p}<0.05)$ and lumbar BMD $(\mathrm{p}<0.05)$ than controls (Table 2 and $\bullet$ Fig. 1). When CS patients were divided into "cured" and "active", the above differences were maintained with respect to controls; additionally cured CS had less LBM than controls (Table 3 ). Active CS had a greater waist-hip ratio $(\mathrm{p}<0.05)$ and less lumbar BMD $(\mathrm{p}<0.01)$ than cured CS.

Regarding cured CS patients that were adrenal insufficient at the time of the DEXA evaluation and required substitution therapy with hydrocortisone, they had less LBM, whole body-BMD and lumbar BMD, more trunk fat in percentage and a greater waisthip ratio than controls ( $\mathrm{p}<0.05, \mathrm{p}<0.01, \mathrm{p}<0.05$, respectively). Additionally they had less lumbar BMD than the cured CS patients $(\mathrm{p}<0.01)$ who did not require hydrocortisone substitution (Table 4).

Cured CS patients who did not require hydrocortisone substitution had more total fat [both in percentage $(\mathrm{p}<0.01)$ and in $\mathrm{kg}$ $(\mathrm{p}<0.01)$ ] and trunk fat [both in percentage $(\mathrm{p}<0.01)$ and in $\mathrm{kg}$ 
Table 3 Body composition parameters in patients diagnosed with Cushing's syndrome (active and cured) and rheumatoid arthritis and controls ${ }^{\mathrm{a}}$

\begin{tabular}{|c|c|c|c|c|c|c|c|}
\hline & $\begin{array}{l}\text { Cured CS } \\
(n=37)\end{array}$ & $\begin{array}{l}\text { Active CS } \\
(n=14)\end{array}$ & $\mathbf{p}^{1}$ & $\mathbf{p}^{2}$ & $\mathrm{p}^{3}$ & $p^{4}$ & $p^{5}$ \\
\hline BMI $\left(\mathrm{kg} / \mathrm{m}^{2}\right)$ & $27.4 \pm 6.7$ & $28.7 \pm 3.1$ & 1.00 & 0.82 & 1.00 & 1.00 & 1.00 \\
\hline Waist hip ratio & $0.89 \pm 0.5$ & $0.93 \pm 0.5$ & $<0.01$ & $<0.01$ & 0.35 & 1.00 & $<0.05$ \\
\hline Total fat mass (\%) & $39.7 \pm 7.4$ & $39.4 \pm 5.9$ & $<0.01$ & $<0.01$ & $<0.05$ & 0.85 & 0.45 \\
\hline Total fat mass $(\mathrm{kg})$ & $27.5 \pm 11.1$ & $27.7 \pm 7.3$ & $<0.05$ & $<0.05$ & $<0.05$ & 0.81 & 0.21 \\
\hline Trunk fat mass (\%) & $40.8 \pm 9.0$ & $40.4 \pm 7.4$ & $<0.01$ & $<0.01$ & $<0.01$ & 0.75 & 0.15 \\
\hline Trunk fat mass (kg) & $14.2 \pm 6.1$ & $14.3 \pm 4.3$ & $<0.01$ & $<0.01$ & 0.12 & 0.82 & 0.77 \\
\hline Lean body mass (kg) & $37.7 \pm 6.4$ & $39.7 \pm 3.9$ & $<0.05$ & 0.92 & 0.31 & 0.01 & 0.35 \\
\hline Whole-BMD $\left(\mathrm{g} / \mathrm{cm}^{2}\right)$ & $1.05 \pm 0.1$ & $1.02 \pm 0.7$ & $<0.01$ & $<0.01$ & $<0.05$ & $<0.05$ & 0.12 \\
\hline Lumbar BMD $\left(\mathrm{g} / \mathrm{cm}^{2}\right)$ & $1.05 \pm 1.1$ & $0.9 \pm 0.1$ & $<0.05$ & $<0.01$ & $<0.05$ & 0.72 & $<0.01$ \\
\hline
\end{tabular}

${ }^{\mathrm{a}} \mathrm{p}^{1}$ between Cured CS and controls; $\mathrm{p}^{2}$ between Active CS and controls; $\mathrm{p}^{3}$ between Cured CS and RA; $\mathrm{p}^{4}$ between Active CS and RA; $\mathrm{p}^{5}$ between Active CS and Cured CS A p-value of $<0.05$ was considered significant. For controls and RA values see Table 2

Table 4 Body composition parameters in patients with cured Cushing's syndrome (with and without replacement therapy with hydrocortisone) and rheumatoid arthritis ${ }^{\mathrm{a}}$

\begin{tabular}{|c|c|c|c|c|c|c|c|}
\hline & $\begin{array}{l}\text { Cured CS with HC } \\
(n=10)\end{array}$ & $\begin{array}{l}\text { Cured CS without HC } \\
(n=27)\end{array}$ & $\mathbf{p}^{1}$ & $\mathbf{p}^{2}$ & $p^{3}$ & $p^{4}$ & $p^{5}$ \\
\hline BMI $\left(\mathrm{kg} / \mathrm{m}^{2}\right)$ & $26.7 \pm 5.6$ & $27.7 \pm 6.4$ & 1.00 & 1.00 & 1.00 & 1.00 & 1.00 \\
\hline Waist hip ratio & $0.89 \pm 0.0$ & $0.90 \pm 0.0$ & $<0.05$ & $<0.01$ & $<0.01$ & 0.82 & 1.00 \\
\hline Total fat mass (\%) & $38.5 \pm 7.2$ & $40.2 \pm 7.5$ & 0.60 & $<0.01$ & 0.07 & $<0.05$ & 0.92 \\
\hline Total fat mass $(\mathrm{kg})$ & $25.1 \pm 12.9$ & $28.4 \pm 10.4$ & 0.80 & $<0.01$ & 0.07 & $<0.05$ & 0.35 \\
\hline Trunk fat mass (\%) & $40.4 \pm 8.8$ & $40.1 \pm 9.2$ & $<0.05$ & $<0.01$ & 0.08 & $<0.05$ & 0.66 \\
\hline Trunk fat mass (kg) & $13.1 \pm 6.6$ & $14.6 \pm 6.1$ & 0.32 & $<0.01$ & 0.72 & 0.15 & 0.39 \\
\hline Lean body mass $(\mathrm{kg})$ & $35.9 \pm 9.4$ & $38.3 \pm 5.0$ & $<0.05$ & 0.16 & 0.20 & 0.14 & 0.34 \\
\hline Whole-BMD $\left(\mathrm{g} / \mathrm{cm}^{2}\right)$ & $1.01 \pm 1.1$ & $1.07 \pm 0.9$ & $<0.01$ & 0.11 & 0.07 & 0.10 & 0.08 \\
\hline Lumbar BMD $\left(\mathrm{g} / \mathrm{cm}^{2}\right)$ & $0.9 \pm 1.1$ & $1.1 \pm 1.1$ & $<0.01$ & 0.92 & 0.06 & $<0.01$ & $<0.01$ \\
\hline
\end{tabular}

${ }^{a} \mathrm{p}^{1}$ between cured CS with hydrocortisone (HC) and controls; $\mathrm{p}^{2}$ between cured CS without $\mathrm{HC}$ and controls; $\mathrm{p}^{3}$ between cured CS with $\mathrm{HC}$ and RA; $\mathrm{p}^{4}$ between cured CS without $\mathrm{HC}$ and RA; $\mathrm{p}^{5}$ between cured CS without $\mathrm{HC}$ and cured CS with $\mathrm{HC}$

A p-value of $<0.05$ was considered significant. For controls and RA values see Table 2

Table 5 Body composition parameters in estrogen deficient (Estrogen-)patients with Cushing's syndrome, rheumatoid arthritis and controls ${ }^{\mathrm{a}}$

\begin{tabular}{|c|c|c|c|c|c|c|}
\hline & $\begin{array}{l}\text { Estrogen-CS } \\
(n=25)\end{array}$ & $\begin{array}{l}\text { Estrogen-RA } \\
(\mathrm{n}=22)\end{array}$ & $\begin{array}{l}\text { Estrogen-controls } \\
(n=40)\end{array}$ & $\mathbf{p}^{1}$ & $p^{2}$ & $\mathbf{p}^{3}$ \\
\hline Age & $60.2 \pm 10.7$ & $65.6 \pm 7.1$ & $61.5 \pm 7.1$ & 1.00 & 1.00 & 1.00 \\
\hline BMI $\left(\mathrm{kg} / \mathrm{m}^{2}\right)$ & $29.3 \pm 5.6$ & $26.8 \pm 5.9$ & $28.4 \pm 5.4$ & 0.82 & 0.94 & 0.80 \\
\hline Waist hip ratio & $0.90 \pm 0.0$ & $0.95 \pm 0.21$ & $0.86 \pm 0.06$ & $<0.05$ & $<0.05$ & 0.55 \\
\hline Total fat mass (\%) & $41.9 \pm 6.1$ & $38.3 \pm 6.1$ & $37.7 \pm 6.6$ & $<0.05$ & 1.00 & $<0.05$ \\
\hline Total fat mass $(\mathrm{kg})$ & $29.8 \pm 10.2$ & $24.0 \pm 8.0$ & $26.5 \pm 7.9$ & 0.05 & 0.82 & $<0.05$ \\
\hline Trunk fat mass (\%) & $44.4 \pm 7.2$ & $37.4 \pm 6.8$ & $37.4 \pm 7.9$ & $<0.01$ & 1.00 & $<0.01$ \\
\hline Trunk fat mass (kg) & $16.2 \pm 5.6$ & $11.5 \pm 3.8$ & $13.2 \pm 4.4$ & $<0.01$ & 0.55 & $<0.01$ \\
\hline Lean body mass (kg) & $37.7 \pm 6.0$ & $35.4 \pm 4.5$ & $40.5 \pm 4.61$ & 0.10 & $<0.01$ & 0.34 \\
\hline Whole-BMD $\left(\mathrm{g} / \mathrm{cm}^{2}\right)$ & $1.02 \pm 0.1$ & $1.08 \pm 0.1$ & $1.08 \pm 0.1$ & 0.30 & 1.00 & 0.41 \\
\hline Lumbar BMD $\left(\mathrm{g} / \mathrm{cm}^{2}\right)$ & $1.0 \pm 0.2$ & $0.9 \pm 0.2$ & $1.04 \pm 0.2$ & 1.00 & 0.72 & 1.00 \\
\hline
\end{tabular}

${ }^{a} p^{1}$ between estrogen-CS and estrogen-controls; $p^{2}$ between estrogen-RA and estrogen-controls; $p^{3}$ between estrogen-CS and estrogen-RA

A p-value of $<0.05$ was considered significant

$(\mathrm{p}<0.01)]$, and a greater waist-hip ratio $(\mathrm{p}<0.01)$ than controls (Table 3). On the other hand they had a greater lumbar BMD $(\mathrm{p}<0.01)$ than CS patients that required substitution therapy with hydrocortisone (Table 4).

\section{Comparisons between CS and RA patients}

CS patients had more total fat (both in percentage and in $\mathrm{kg}$ ) and trunk fat in percentage and less whole body BMD than patients with RA $(\mathrm{p}<0.05, \mathrm{p}<0.01, \mathrm{p}<0.05$, respectively) (Table 2 and $\odot$ Fig. 1).

Cured CS patients, both globally and those cured who did not require hydrocortisone, had more total fat [both in percentage $(\mathrm{p}<0.05)$ and in $\mathrm{kg}(\mathrm{p}<0.05)]$, trunk fat in percentage $(\mathrm{p}<0.01$ and $\mathrm{p}<0.05)$, lumbar BMD $(\mathrm{p}<0.05$ and $\mathrm{p}<0.01)$ than $\mathrm{RA}$ patients. Additionally the global CS group also had less whole body-BMD $(p<0.05)$ than RA patients. Patients with active CS had less whole body-BMD and more LBM than RA patients ( $\mathrm{p}<0.05$ and $\mathrm{p}=0.01$ respectively) (Table 3 ).

Cured CS patients still requiring hydrocortisone substitution therapy only differed from RA patients by a smaller waist-hip ratio $(p<0.01)$, but were otherwise not different in any of the other body composition parameters evaluated (Table 4). No differences in BMI within the 3 studied groups were observed. 


\section{Role of GH deficiency}

When the data were reanalyzed excluding the CS patients with GH deficiency without replacement therapy $(n=4)$ the same results were found.

\section{Role of estrogens}

Because estrogens play an important role on bone, CS patients, RA patients and controls were divided into an estrogen-sufficient group (including premenopausal with regular menses and postmenopausal women with hormone replacement therapy) and an estrogen-deficient group (including postmenopausal and premenopausal women with no replacement for hypogonadism). When data were reanalyzed comparing only the estrogendeficient groups, all the differences in lumbar BMD and whole body-BMD disappeared. The other differences in body composition parameters, however, remained the same (Table 5).

\section{Discussion}

While exposure to endogenous hypercortisolism due to CS is a rare situation, chronic treatment with exogenous GC is common in clinical practice for a variety of causes. There is a general consensus that the shortest period at the lowest possible dose of GC is desirable to prevent side effects, but there is little awareness that low doses may also be harmful. For this reason we compared body composition after exposure to endogenous hypercortisolism (due to Cushing's syndrome) and exogenous GC treatment (with low-dose prednisone in rheumatoid arthritis). Increased total and central body fat is a common feature of CS $[14,15]$. Waist-hip ratio is an abdominal fat distribution index, predictor of cardiovascular risk [16], and is more sensitive than BMI to evaluate clustering of coronary risk factors among nonobese men and women [16]. Since the women with RA were older than those with CS, a statistical analysis using age as covariant was performed in order to make the groups comparable and avoid the effect of age.

We found that both patients with CS and RA have a higher waisthip ratio than controls, with no difference between them, consequently indicating a higher cardiovascular risk. This would suggest that the waist-hip ratio might be used in clinical practice to assess cardiovascular risk both in CS and RA patients. Moreover, persistence of increased total and central body fat has been reported in patients with cured CS $[17,18]$. This increase in trunk fat is a common complaint of patients who have suffered from CS and also those who have been treated with high doses of exogenous GC. Given the increased cardiovascular risk conferred by central obesity, this persistence in trunk fat may contribute to long-term morbidity in these patients, despite endocrine control $[17,19]$.

A possible explanation for the persistent increase in trunk fat may be the effect of cortisol on the omental adipose tissue; after hypercortisolism has disappeared, the increased number of fat cells, enhanced by cortisol, remains and can contribute to explain the persistent increase in abdominal fat deposits [20-22]. A dysregulation in the hypothalamic-pituitary-adrenal (HPA) axis could also be involved [23]. Another novel mechanism that explains the deposition of visceral adipose tissue and consequent central obesity in patients with iatrogenic or endogenous CS is the inhibition of AMPK activity in adipose tissue by GC [24].
The coexistence of GH deficiency in patients with Cushing's disease after long-term remission of hypercortisolism obtained by surgery, by itself may affect body composition [25-27]. Male gender and length of hypercortisolism are the most significant predictors of postsurgical GH deficiency; our study only included women and few GH deficiency, these could be the reasons why no effect of GH deficiency on body composition was found.

Estrogens exert an important effect on normal bone density and estrogen deficiency is associated with bone loss [28] as well as an increase in total and trunk fat when compared to healthy controls [29]. In this study we show that the lower values of BMD in CS and RA, when compared to controls, disappeared when only estrogen-deficient women were compared, highlighting that once the protective effect of estrogen is lost, GC exposure is less important for the bone, be it of endogenous or exogenous origin. This is clearly different from the effect on the fat, since CS has greater body fat, independently of the estrogen status; this would confer to these patients a persistent higher cardiovascular risk.

The deleterious effects of glucocorticoid replacement on bone in estrogen-sufficient women after long-term remission of Cushing's Syndrome has been recently demonstrated; the damage done to bone during endogenous hypercortisolism may have contributed to determine a worse response to subsequent GC replacement [30]. The exact mechanism is not known, in the literature the mevalonate pathway is involved in glucocorticoidinduced osteoblast dysfunction [31].

Patients with RA had less lean body mass (LBM) than controls and less than active CS, even when only estrogen deficient women were compared. Less lean body mass has been described in RA [32], probably related to less muscle exercise due to articular pain in these patients. From our study it appears that neither GC exposure nor estrogen status play a further role on LBM in these RA patients.

It is not so clear why CS patients have more severe changes in body composition than RA patients. This is the first study to address and compare this issue. Since the length of glucocorticoid exposure is quite similar, we could hypothesize, based on clinical experience and on the literature, that chronic, continuous, throughout $24 \mathrm{~h}$, endogenous exposure over months or years to severe hypercortisolism, has a greater effect on body composition than daily prednisone treatment administrated once a day, as occurs in RA. As demonstrated previously [14], the cumulative exposure to GC in CS does not appear to be a determinant factor.

In conclusion, prior exposure to endogenous hypercortisolism in CS determines an irreversible increase in body fat, greater than that seen in RA treated with low dose prednisone. Endogenous and exogenous exposure to GC negatively affects body composition by increasing the waist-hip ratio. There appears to be no additional effect on BMD in estrogen deficient women.

\section{Acknowledgements}

$\nabla$

We thank Dr. Ignasi Gich, from the Department of Epidemiology of the Hospital Sant Pau, for the critical review of the statistical analysis. The collaboration of the patients who participated in this study is also acknowledged. 


\section{References}

1 Burt MG, Gibney J, Ho KK. Characterization of the metabolic phenotypes of Cushing's syndrome and growth hormone deficiency: a study of body composition and energy metabolism. Clin Endocrinol 2006; 64: 436-443

2 Shaker JL, Lukert BP. Osteoporosis associated with excess glucocorticoids. Endocrinol Metab Clin N Am 2005; 34: 341-356

3 Fernandez-Rodriguez E, Stewart PM, Cooper MS. The pituitary-adrenal axis and body composition. Pituitary 2009; 12: 105-115

4 Niu CS, Yeh CH, Yeh MF, Cheng JT. Increase of adipogenesis by ginsenoside (Rh2) in 3T3-L1 cell via an activation of glucocorticoid receptor. Horm Metab Res 2009; 41: 271-276

5 Rockall AG, Sohaib SA, Evans D, Kaltsas G, Isidori AM, Monson JP, Besser $G M$, Grossman AB, Reznek RH. Computed tomography assessment of fat distribution in male and female patients with Cushing's syndrome. Eur J Endocrinol 2003; 149: 561-567

6 Ueland T, Kristo C, Godang K, Aukrust P, Bollerslev J. Interleukin-1 receptor antagonist is associated with fat distribution in endogenous Cushing's syndrome: a longitudinal study. J Clin Endocrinol Metab 2003; 88: 1492-1496

7 Pirlich M, Biering H, Gerl H, Ventz M, Schmidt B, Ertl S, Lochs H. Loss of body cell mass in Cushing's syndrome: effect of treatment. J Clin Endocrinol Metab 2002; 87: 1078-1084

8 Colao A, Pivonello R, Spiezia S, Faggiano A, Ferone D, Filippella M, Marzullo P. Cerbone G, Siciliani M, Lombardi G. Persistence of increased cardiovascular risk in patients with Cushing's disease after 5 years of successful cure. J Clin Endocrinol Metab 1999; 84: 2664-2672

9 Lewis JG, Borowski KK, Shand BI, George PM, Scott RS. Plasma sex hormone-binding globulin, corticosteroid-binding globulin, cortisol, and free cortisol levels in outpatients attending a lipid disorders clinic: a cross-sectional study of 1137 subjects. Horm Metab Res 2010; 42: 274-279

10 Majithia V, Geraci SA. Rheumatoid arthritis: diagnosis and management. Am J Med 2007; 120: 936-939

11 Boland EW, Headley NE. Results of long-continued cortisone administration in rheumatoid arthritis. Calif Med 1975; 74: 416-423

12 Arnett FC, Edworthy SM, Bloch DA, McShane DJ, Fries JF, Cooper NS, Healey LA, Kaplan SR, Liang MH, Luthra HS, Medsger TA Jr, Mitchel DM, Neustadt DH, Pinals RS, Schaller JG, Sharp JT. The American Rheumatism association 1987. Revised criteria for the classification of Rheumatoid Arthritis. Arthritis Rheum 1988; 31: 315-323

13 Wilson TA, Blizzard RM. Adrenal insufficiency in childhood. In: Lavin N (ed.) Manual of Endocrinology and Metabolism. Boston: Little, Brown \& Co; 1986;189

14 Arnaldi G, Mancini T, Polenta B, Boscaro M. Cardiovascular risk in Cushing's syndrome. Pituitary 2004; 7: 253-256

15 Albiger N, Testa RM, Almoto B, Ferrari M, Bilora F, Petrobelli F, Pagnan $A$, Mantero F, Scaroni C. Patients with Cushing's syndrome have increased intimal media thickness at different vascular levels: comparison with a population matched for similar cardiovascular risk factors. Horm Metab Res 2006; 38: 405-410

16 Huxley R, Mendis S, Zheleznyakov E, Reddy S, Chan J. Body mass index, waist circumference and waist-hip ratio as predictors of cardiovascular risk-a review of the literature. Eur J Clin Nutr 2010; 64: 16-22

17 Barahona MJ, Sucunza N, Resmini E, Fernández-Real JM, Ricart W, Moreno-Navarrete JM, Puig T, Farrerons J, Webb SM. Persistent body fat mass and inflammatory marker increases after long-term cure of Cushing's syndrome. J Clin Endocrinol Metab 2009; 94: 3365-3371
18 Leong GM, Abad V, Charmandari E, Reynolds JC, Hill S, Chrousos GP, Nieman LK. The effects of child-and adolescent-onset endogenous Cushing syndrome on bone mass, body composition and growth: a 7-year prospective study into young adulthood. J Bone Miner Res 2007; 22: $110-118$

19 Pivonello R, Faggiano A, Lombardi G, Colao A. The metabolic syndrome and cardiovascular risk in Cushing's syndrome. Endocrinol Metab Clin N Am 2005; 34: 327-339

20 Stewart PM. Tissue-specific Cushing's syndrome, 11ß-hydroxysteroid dehydrogenases and the redefinition of corticosteroid hormone action. Eur J Endocrin 2003; 149: 163-168

21 Tomlinson JW, Walker EA, Bujalska IJ. 11ß-Hydroxysteroid Dehydrogenase type 1: a tissue-specific regulator of glucocorticoid response. End Rev 2004; 25: 831-866

22 Bujalska IJ, Kumar S, Stewart PM. Does central obesity reflect "Cushing's disease of the omentum"? The Lancet 1997; 349: 1210-1213

23 Chrousos GP. The role of stress and the hypothalamic-pituitary-adrenal axis in the pathogenesis of the metabolic syndrome: neuro-endocrin and target tissue-related causes. Int J Obes 2000; 24: 50-55

24 Kola B, Christ-Crain M, Lolli F, Arnaldi G, Giacchetti G, Boscaro M, Grossman $A B$, Korbonits $M$. Changes in AMP-activated protein kinase as a mechanism of visceral obesity in Cushing's syndrome. J Clin Endocrinol Metab 2008; 93: 4969-4973

25 Pecori Giraldi F, Andrioli M, De Marinis L, Bianchi A, Giampietro A, De Martin M, Sacco E, Scacchi M, Pontecorvi A, Cavagnini F. Significant GH deficiency after long-term cure by surgery in adult patients with Cushing's disease. Eur J Endocrinol 2007; 156: 233-239

26 Burt MG, Gibney J, Ho KK. Characterization of the metabolic phenotypes of Cushing's syndrome and growth hormone deficiency: a study of body composition and energy metabolism. Clin Endocrinol (Oxf) 2006; 64: 436-443

27 Webb SM, Mo D, Lamberts SW, Melmed S, Cavagnini F, Pecori Giraldi F, Strasburger CJ, Zimmermann AG, Woodmansee WW. Metabolic, cardiovascular, and cerebrovascular outcomes in growth hormone-deficient subjects with previous Cushing's disease or non-functioning pituitary adenoma. J Clin Endocrinol Metab 2010; 95: 630-638

28 McLeod KM, Johnson CS. Identifying women with low bone mass: a systematic review of screening tools. Geriatr Nurs 2009; 30: 164-173

29 Sherk VD, Palmer IJ, Bemben MG, Bemben DA. Relationships between body composition, muscular strength, and bone mineral density in estrogen-deficient postmenopausal women. J Clin Densitom 2009; 12: 292-298

30 Barahona MJ, Sucunza N, Resmini E, Fernández-Real J, Ricart W, Moreno J, Puig T, Wägner A, Rodriguez-Espinosa J, Farrerons J, Webb S. Deleterious effects of glucocorticoid replacement on bone in women after long-term remission of Cushing's syndrome. J Bone Miner Res 2009; 24: $1841-1846$

31 Kanazawa I, Yamaguchi T, Yano S, Hayashi K, Yamauchi M, Sugimoto T. Inhibition of the mevalonate pathway rescues the dexamethasoneinduced suppression of the mineralization in osteoblasts via enhancing bone morphogenetic protein-2 signal. Horm Metab Res 2009; 41: 612-616

32 Westhovens R, Nijs J, Taelman V, Dequeker J. Body composition in rheumatoid arthritis. Br J Rheumatol 1997; 36: 444-448 